\title{
HUBUNGAN MODAL SOSIAL DENGAN KESEJAHTERAAN EKONOMI KELUARGA DI DAERAH PERDESAAN JAMBI
}

\author{
Suandi ${ }^{\bowtie}$ \\ Jurusan Agribisnis, Fakultas Pertanian, Universitas Jambi, Indonesia
}

Permalink/DOI: http://dx.doi.org/10.15294/komunitas.v6i1.2940

\begin{tabular}{l} 
Article History \\
\hline Received : Desember 2013 \\
Accepted : Januari 2014 \\
Published : Maret 2014
\end{tabular}

\section{Keywords}

community character, family economic wellbeing; local associations; poverty; social capital

\begin{abstract}
Abstrak
Tujuan penelitian adalah menganalisis pengaruh modal sosial terhadap kesejahteraan ekonomi keluarga di daerah perdesaan Kabupaten Kerinci. Desain penelitian adalah cross sectional. Penelitian dilakukan di Kabupaten Kerinci dengan memilih dua kecamatan, yaitu: Kecamatan Keliling Danau, dan Kecamatan Batang Merangin. Waktu penelitian secara keseluruhan dilakukan dari bulan Juni sampai dengan bulan Nopember 2012. Sampel penelitian sebanyak 132 keluarga atau 1o persen dari populasi (1.316 keluarga) yang diambil secara berturut-turut dengan cara cluster, purposive, dan simple random sampling. Variabel penelitian: (1) kesejahteraan ekonomi keluarga (kesejahteraan objektif, dan kesejahteraan subjektif, dan (2) Modal sosial (asosiasi lokal dan karakter masyarakat). Analisis data menggunakan model Structural Equation Modelling (SEM) melalui program LISREL. Hasil penelitian menunjukkan bahwa modal sosial (asosiasi lokal dan karakter masyarakat) responden tergolong kuat. Mengacu kepada alokasi pengeluaran, tingkat ekonomi petani di daerah penelitian tergolong relatif kaya dengan distribusi keluarga yang tergolong pada kelompok sejahtera mencapai 78,8 persen, sedangkan kelompok miskin hanya 21,2 persen. Modal sosial (asosiasi lokal dan karakter masyarakat) baik secara langsung maupun tidak langsung berpengaruh positif sangat nyata terhadap kesejahteraan ekonomi keluarga.
\end{abstract}

\section{THE RELATIONSHIPS BETWEEN SOCIAL CAPITAL AND FAMILY ECONOMIC WELL-BEING IN RURAL AREAS: EVIDENCES FROM JAMBI}

\begin{abstract}
The objectives of this study is to analyze the effect of social capital on family economic well-being in rural areas of Kerinci regency. The research design is cross sectional and was carried out in Batang Merangin and Keliling Danau districts from June to Nopember 2012. Variables used are social capital (local associations and community character), and family economic well-being both objective and subjective economic well-being. 132 household samples are chosen using cluster, purposive and random sampling methods. Data were collected using survay, indepth interview, and Focus Group Discussion (FGD). Descriptive, and Structural Equation Modeling (SEM) models were used fordataanalyzed. The results show that social capital (localassociations and community character) contained in the study area as strong. Referring to the allocation of family expenditure, the economic level of family in the study area are relatively wealthy families with distributions belonging to the prosperous group reached 78.8 percent, while only the poor families as much as 21.2 percent. Social capital (local associations and community character) both directly and indirectly has a significant effect on family economic well-being.
\end{abstract}

(c) 2014 Universitas Negeri Semarang

\footnotetext{
Corresponding author:

Alamat : Jln. A. Manaf Telanaipura - Jambi 36124

E-mail : wandy_ipb@yahoo.com
}

ISSN 2086-5465 


\section{PENDAHULUAN}

Penduduk Provinsi Jambi dikenal dengan tiga kelompok komunitas masyarakat, yakni: masyarakat yang berada pada wilayah dataran rendah, dataran tinggi atau pegunungan dan wilayah pesisir pantai atau pasang surut. Wilayah dataran rendah misalnya, didominasi oleh masyarakat Melayu ditambah dengan pendatang (transmigran dari Jawa dan Bali) dengan hasil utama karet dan kelapa sawit, wilayah pesisir pantai atau pasang surut didominasi oleh masyarakat Melayu, Bugis dan Banjar (migrasi spontan) dengan komoditas utama perikanan laut, perkebunan kelapa dalam dan usaha tani padi sawah pasang surut, sedangkan di wilayah dataran tinggi atau pegunungan didominasi oleh suku Melayu-Kerinci dengan komoditas utama perkebunan kulit manis (cassiavera), kopi dan usaha tani padi sawah irigasi. Dengan kata lain, Provinsi Jambi terutama di wilayah dataran tinggi atau pergunungan memiliki tingkat kekerabatan atau ikatan kekeluargaan satu sama lainnya cukup kuat karena sebagian besar masyarakat terdiri dari satu kelompok kerukunan adat.

Tingginya tingkat kerukunan adat sehingga di daerah pegunungan terkenal dengan kekayaan stuktur dan kebersamaan masyarakat baik antarindividu maupun kelompok atau masyarakat sehingga sangat bermanfaat bagi keluarga untuk meningkatkan kesejahteraan. Kesejahteraan diartikan suatu tata nilai kehidupan dan penghidupan bagi setiap individu, keluarga dan masyarakat terhadap berbagai aspek, seperti: ekonomi, sosial, maupun spritual untuk mengadakan usaha-usaha pemenuhan kebutuhan jasmani dan rohani. Untuk mencapai tujuan tersebut diperlukan tingkat koneksi yang kuat dan intensif dalam memanfaatkan modal sosial yang dimiliki.

Mengingat modal sosial merupakan sumberdaya terpenting dalam kehidupan masyarakat karena modal ini merupakan jaringan/hubungan keluarga terhadap dunia luar baik bersifat formal maupun informal untuk memecahkan berbagai persoalan yang ada di masyarakat termasuk masalah kebutuhan pangan keluarga. Dengan arti kata, modal sosial merupakan bentuk jaringan kerja sosial dan ekonomi di masyarakat yang terjadi antarindividu dan kelompok yang bermanfaat dan menguntungkan (Suandi, 2011). Sesuai dengan konsep yang dikembangkan dalam penelitian ini dan didukung oleh sosial budaya masyarakat Jambi umumnya maka dimensi modal sosial yang digunakan yaitu terdiri dari dua dimensi yang saling berhubungan secara kausalitas, yakni: asosiasi lokal/organisasi sosial dan dimensi karakter masyarakat itu sendiri. Dimensi asosiasi lokal dilihat dari aspek: jumlah asosiasi yang diikuti, tingkat partisipasi, manfaat asosiasi, dan tingkat heterogenitas asosiasi yang diikuti masyarakat. Artinya, semakin banyak asosiasi yang diikuti dengan tingkat partisipasi tinggi serta heterogenitas asosiasi yang mereka ikuti cukup beragam maka akan berdampak terhadap penghasilan dan ekonomi rumahtangga, termasuk kebutuhan akan pangan dan sebaliknya. Kemudian, dimensi karakter yang terdiri dari: keterpercayaan, solidaritas, dan dimensi semangat kerja akan mencerminkan keuletan dan ketergantungan mereka dengan masyarakat luas termasuk ketergantungan dalam konsumsi pangan rumahtangga. Apabila pola ini dilaksanakan secara berkelanjutan dan bersinergi dengan modal lainnya, maka keterbatasan masyarakat baik secara ekonomi, sosial maupun kebutuhan akan pangan dapat teratasi sehingga pada gilirannya model ini dapat diterapkan di masyarakat secara luas terutama di daerah perdesaan.

\section{METODE PENELITIAN}

Desain penelitian adalah cross sectional. Penelitian dilakukan di Kabupaten Kerinci dengan dua kecamatan terpilih, yaitu: Kecamatan Keliling Danau dan Kecamatan Batang Merangin. Data penelitian bersumber dari data primer dan sekunder. Data primer diperoleh langsung dari keluarga dan responden terpilih, sedangkan data sekunder diperoleh dari instansi dan lembaga terkait disamping dari laporan hasil penelitian, jurnal maupun majalah yang memuat tentang masalah modal sosial dan kesejahteraan, sedangkan jenis atau variabel penelitian di- 
bagi ke dalam dua kelompok, yaitu: modal sosial, dan variabel kesejahteraan (objektif dan subjektif).

Variabel modal sosial dibagi dalam dua dimensi, yakni dimensi asosiasi lokal, dan dimensi karakter masyarakat. Variabel yang termasuk kedalam dimensi asosiasi lokal, meliputi: (1) jumlah kelompok/organisasi yang diikuti, (2) tingkat partisipasi keluarga dalam kelompok/organisiasi, dan (3) manfaat kelompok/ organisasi, sedangkan untuk dimensi karakter masyarakat, meliputi: (1) kepercayaan, (2) solidaritas, dan (3) semangat kerja. Aspek kesejahteraan ekonomi keluarga dibagi dalam dua dimensi, yakni kesejahteraan ekonomi objektif dan kesejahteraan ekonomi subjektif. Variabel kesejahteraan ekonomi objektif, meliputi: (1) kebutuhan pangan, (2) kebutuhan nonpangan, dan (3) kebutuhan investasi sumberdaya manusia, sedangkan variabel yang diteliti untuk kesejahteraan subjektif yaitu melihat tingkat kepuasan keluarga, meliputi: (1) pemenuhan kebutuhan pangan, (2) nonpangan, dan (3) pemenuhan kebutuhan investasi sumberdaya manusia. Untuk mendapatkan data lebih mendalam, pe- ngumpulan data dilanjutkan dengan metode wawancara mendalam (Indepth Interview) terhadap beberapa responden terpilih dan Focus Group Discussion (FGD).

Daerah penelitian ditentukan dengan metode cluster sampling sehingga terpilih wilayah relatif datar dan daerah dataran tinggi (pegunungan) yaitu kecamatan Keliling Danau, dan Kecamatan Batang Merangin. Diambilnya daerah/wilayah penelitian berdasarkan agroekologi, mengingat distribusi penduduk Kabupaten Kerinci menyebar berdasarkan tipologi tersebut. Selanjutnya, desa/kelurahan penelitian diambil secara purposive dan mengikuti pola yang ada di masing-masing wilayah kecamatan, sedangkan responden (rumahtangga) diambil secara acak sederhana (simple random sampling) sebesar 132 orang atau 10 persen dari jumlah rumahtangga yang ada pada seluruh desa penelitian (1.324 rumahtangga). Untuk menjawab tujuan penelitian tentang pengaruh modal sosial terhadap kesejahteraan ekonomi keluarga di daerah penelitian dianalisis dengan menggunakan Struktural Equation Modeling (SEM) dengan program Linear Structural Releationship (LISREL) versi 8.8 .

\section{HASIL DAN PEMBAHASAN \\ Modal Sosial}

Modal sosial merupakan bentuk jaringan kerja sosial dan ekonomi di masyarakat yang terjadi antar individu dan kelompok baik formal maupun informal yang bermanfaat dan menguntungkan. Modal sosial dikategorikan melalui dua dimensi yang saling berhubungan (interrelated), yakni: dimensi struktural, dan dimensi karakter ${ }^{1}$. Dimensi struktural diukur dalam bentuk kelompok dan organisasi (asosiasi lokal). Tinggi rendah kontribusi asosiasi lokal terhadap kesejahteraan keluarga diukur secara komposit dari dimensi (a) jumlah asosiasi yang diikuti, (b) tingkat partisipasi dalam asosiasi, dan (c) manfaat asosiasi dengan nilai sebagai berikut: (1) sangat rendah, (2) rendah, (3) tinggi, dan (4) sangat tinggi, sedangkan dimensi karakter diukur dari nilai komposit: (a) tingkat keterpercayaan, (b) solidaritas, dan (c) semangat kerja dengan nilai: (1) sangat rendah, (2) rendah, (3) tinggi, dan (4) sangat tinggi.

\section{Asosiasi Lokal}

Jumlah Asosiasi Lokal yang diikuti. Jumlah asosiasi lokal yang diikuti keluarga contoh di daerah penelitian dikelompokkan menjadi empat golongan, yaitu: sangat sedikit (satu asiosiasi), sedikit (dua asosiasi), banyak (tiga asosiasi), dan sangat banyak (lebih dari tiga asosiasi). Hasil pengamatan lapangan diperoleh bahwa jumlah asosiasi lokal yang diikuti keluarga contoh di daerah penelitian tergolong besar karena lebih dari 65 persen keluarga contoh mengikuti sebanyak tiga atau lebih asosiasi lokal. Dengan semakin banyaknya jumlah asosiasi lokal yang diikuti oleh anggota keluarga contoh diharapkan dapat mendukung atau mem-

1 Konsep ini mengacu pada konsep yang dikembangkan oleh Bourdieu (1986), Coleman (1988), dan Putnam, Leonardi, dan Nanetti (1993), Grootaert (1997), Woolcock (1998), Fukuyama (1999), Uphoff (1999) (Dasgupta P., 2000:218), dan Flores dan Fernando (2003) (disempurnakan). 
pengaruhi tingkat kebersamaan dan solidaritas sesama anggota masyarakat sehingga pada gilirannya akan berdampak terhadap kesejahteraan dan kemajuan desa.

\section{Tingkat Partisipasi Anggota Keluarga.}

Tingkat partisipasi anggota keluarga contoh dalam asosiasi lokal dilihat dari dua aspek, yakni: tingkat keaktifan dalam pertemuan dan pengambilan keputusan selama mengikuti pertemuan. Data menunjukkan, terdapat sebanyak 70,5 persen dari seluruh keluarga contoh merupakan anggota yang aktif dan sangat aktif dalam asosiasi. Berdasarkan tingkat partisipasi dalam pertemuan, di mana tingkat partisipasi anggota keluarga sangat tinggi sekali yaitu mencapai angka 82 persen dengan frekuensi pertemuan lebih dari 75 persen dan bahkan 70 persen diantaranya aktif mengikuti pertemuan kelompok/organisasi setiap kali pertemuan. Melihat dari tingkat frekuensi pertemuan anggota keluarga contoh dalam asosiasi yang diikuti ini menunjukkan bahwa keterkaitan keluarga contoh dengan asosiasi lokal yang berkembang di masyarakat cukup kuat.

\section{Manfaat Kelompok/Organisasi bagi Keluarga.}

Faktor manfaat secara struktural merupakan elemen penting dalam modal sosial karena faktor ini berkaitan erat dengan keterlibatan anggota masyarakat dalam asosiasi. Artinya, semakin besar nilai manfaat dari suatu asosiasi bagi keluarga maka kontribusi setiap anggota keluarga semakin besar dan sebaliknya. Manfaat asosiasi bagi keluarga contoh di daerah penelitian $\mathrm{cu}^{-}$ kup besar hal ini ditandai dengan tingginya proporsi keluarga yang menyatakan bahwa asosiasi lokal bermanfaat dan sangat bermanfaat (66,6 \%). Dari hasil Focus Group Discussion (FGD) di desa Koto Agung Kecamatan Keliling Danau menyimpulkan bahwa asosiasi desa yang ada di daerah ini baik asosiasi formal maupun informal cukup penting dalam meningkatkan perekonomian dan hubungan sosial dalam masyarakat terutama "sistem kerja gotong royong (collective action) untuk pembangunan fasilitas umum.

\section{Karakter Masyarakat}

Karakter seorang individu merupakan "the sum total of the disinguishing qualities of a person" atau sering juga disebut dengan istilah "moral exellence and strength" (Webster: Hastuti, 2006: 11). Ditambahkan oleh Lichona (Hastuti, 2006: 11), bahwa karakter terdiri dari tiga dimensi yang saling terkait satu sama lainnya, yakni: pengetahuan tentang moral (moral knowing), perasaan tentang moral (moral feeling), dan perilaku bermoral (moral behavior). Artinya, seorang individu yang berkarakter baik apabila individu tersebut dapat mengetahui tentang berbagai kebaikan (knowing the good), menginginkan dan selalu mencintai kebaikan (loving the good), dan selalu melakukan berbagai tindakan yang baik (acting the good). Implementasi dalam kehidupan sehari-hari dan seorang individu yang berkarakter baik dapat dilihat pada pola hidup dan interaksi sosial mereka dengan masyarakat dalam konteks: nilai keterpercayaan, solidaritas dan semangat kerja. Nilai keterpercayaan diukur dari tiga dimensi, yaitu: komitmen terhadap norma yang berlaku, kejujuran, dan tanggung jawab. Solidaritas masyarakat dilihat dari aspek: tingkat ketergantungan antaranggota masyarakat, saling bantu membantu, dan aspek kepekaan terhadap kemajuan desa, sedangkan aspek semangat kerja diukur dari disiplin dan keuletan kerja masyarakat.

\section{Tingkat Keterpercayaan Masyarakat.}

Keterpercayaan diukur dalam bentuk tingkat keyakinan seseorang terhadap perkataan, perjanjian, dan tindakan secara konsisten pada saat terjalinnya hubungan antar individu atau kelompok/organisasi dalam masyarakat. Tingkat keterpercayaan seseorang dapat dilihat dari dimensi: tingkat komitmen, kejujuran dan tanggung jawab. Data menunjukkan bahwa tingkat keterpercayaan masyarakat di daerah penelitian tergolong relatif baik karena hasil perhitungan diperoleh proporsi keluarga contoh yang tergolong pada kelompok keterpercayaan tinggi dan sangat tinggi yaitu mencapai 73,5 
persen. Artinya, hampir 75 persen masyarakat di daerah perdesaan Kabupaten Kerinci memiliki tingkat keterpercayaan tinggi. Relatif tingginya tingkat keterpercayaan masyarakat yang ada di Kabupaten Kerinci sangat terkait dengan pola hubungan individu dalam masyarakat. Pola hubungan atau interaksi individu dalam masyarakat Kerinci yaitu menganut sistem "kalbu." Sistem kalbu adalah interaksi sosial/hubungan sosial masyarakat dalam kelompok atau turunan tertentu yang dibingkai dalam sebuah kedepatian dan lembaga adat dengan satu tujuan. Artinya, satu depati dengan depati yang lain saling kait mengkait dan saling ketergantungan untuk membangun sebuah kelembagaan yang kokoh yang disebut dengan "kelembagaan adat."

\section{Tingkat Solidaritas Masyarakat}

Solidaritas masyarakat merupakan kondisi masyarakat saling mau menerima, memiliki sebagai anggota dari sebuah sistem, saling bergantung satu sama lain, mereka saling percaya untuk memenuhi keinginan bersama sehingga ketentraman dan keharmonisan dapat tercapai. Tinggi rendahnya tingkat solidaritas masyarakat dilihat dari tiga dimensi: ketergantungan satu sama lainnya, saling bantu membantu, dan adanya kepekaan terhadap kemajuan desa. Hasil analisis menunjukkan bahwa tingkat solidaritas masyarakat di daerah penelitian sedikit lebih baik dari tingkat keterpercayaan masyarakat yakni mencapai 78,8 persen. Hal ini dapat dimaklumi bahwa tingginya tingkat solidaritas masyarakat di daerah perdesaan Kabupaten Kerinci seperti yang telah dijelaskan sebelumnya karena kuatnya kelembagaan adat yang ada di daerah tersebut.

\section{Semangat Kerja Masyarakat}

Seorang individu atau kelompok masyarakat dikatakan atau dicirikan sebagai seorang semangat kerja tinggi (tipe pekerja keras) apabila mereka selalu melakukan kegiatan dengan disiplin (ulet, pantang menyerah) dan melakukan pekerjaan dengan segera serta memanfaatkan waktu dengan efektif dan efisien. Data lapangan menun- jukkan bahwa semangat kerja keluarga contoh yang dapat digolongkan pada kelompok masyarakat dengan tipe bekerja keras hanya 52 persen. Dengan kata lain, proporsi tenaga kerja yang memiliki tingkat etos kerja tinggi hanya separo dari jumlah responden yang diwawancarai, namun angka ini jauh lebih tinggi dibandingkan tipe kerja masyarakat Jambi secara keseluruhan (38 \%) (Suandi, 2011). Hal ini mengindikasikan bahwa etos kerja masyarakat di daerah penelitian hampir tergolong tinggi.

\section{Kesejahteraan Ekonomi Keluarga}

Menurut Lokshin dan Ravallion (Strauss, 2004: 63), pengertian kesejahteraan dilihat dari dua pendekatan, yakni: kesejahteraan objektif dan kesejahteraan subjektif. Noll (Milligan et al., 2006: 22), melihat bahwa kesejahteraan objektif adalah tingkat kesejahteraan individu atau kelompok masyarakat yang diukur secara rata-rata dengan patokan tertentu baik ukuran ekonomi, sosial maupun ukuran lainnya. Dengan kata lain, tingkat kesejahteraan masyarakat diukur dengan pendekatan yang baku (tingkat kesejahteraan masyarakat semuanya dianggap sama), sedangkan kesejahteraan subjektif adalah tingkat kesejahteraan seorang individu yang dilihat secara personal yang diukur dalam bentuk kepuasan dan kebahagiaan.

Teori yang dikemukakan oleh Noll sejalan dengan hasil penelitian Sumarti, (Suandi, 2011) bahwa kesejahteraan subjektif individu atau keluarga adalah wujud kebudayaan yang dihasilkan melalui proses pengalaman hidup sekelompok manusia dalam hubungannya dengan lingkungan (fisik dan sosial). Artinya, pengertian kesejahteraan haruslah berpedoman kepada subjektivitas (lokal) masyarakat setempat. Namun demikian, inti dari kesejahteraan adalah melihat kesenjangan antara aspirasi dengan tujuan yang ingin dicapai pada segolongan masyarakat maka menurut Campbell, Converse, dan Rodgers (Sumarwan dan Hira: Suandi, 2011), tolok ukur yang relevan dan akurat tentang kesejahteraan subjektif adalah menggunakan istilah "kepuasan." 


\section{Kesejahteraan Ekonomi Objektif}

Kesejahteraan ekonomi objektif keluarga di wilayah penelitian diukur dengan proxy besarnya pengeluaran keluarga. Pengeluaran keluarga yaitu pengeluaran yang diperuntukkan pembelian kebutuhan keluarga sehari-hari, yakni kebutuhan pokok dan kebutuhan lainnya. Dengan kata lain, pengeluaran keluarga dialokasikan untuk kebutuhan pangan, nonpangan dan investasi. Porsi pengeluaran tersebut akan mencerminkan tingkat kesejahteraan suatu kelompok masyarakat (Mangkuprawira, 2002: 74). Hasil pengamatan lapangan, terdapat perbedaan yang cukup mencolok antara pengeluaran kecil (miskin) dengan pengeluaran relatif besar (keluarga berkecukupan). Distribusi pengeluaran pada kelompok hampir berkecukupan keatas mencapai 78,8 persen atau hampir mendekati 8 o persen (Tabel 4.1). Hal ini menunjukkan bahwa keluarga di daerah penelitian berdasarkan pada tingkat pengeluaran dapat di kategorikan pada kelompok sejahtera.

Apabila tingkat pengeluaran keluarga contoh dikalikan dengan jumlah anggota keluarga, diperoleh tingkat pengeluaran total keluarga pertahun sebesar Rp. 19.310.00o,oo, dan jumlah pengeluaran ini diatas rata-rata tolok ukur kesejahteraan dengan pendekatan Badan Pusat Statistik (Rp.13.710.00o,oo)(BPS Provinsi Jambi, 2012). Di mana rata-rata UMP Provinsi Jambi pada tahun 2012, yaitu sebesar Rp.1.142.500,oo per bulan. Dari jumlah pengeluaran tersebut persentase terbesar dia- lokasikan untuk pangan (50,6 \%), kemudian diikuti pengeluaran non-pangan (sandang, energi, komunikasi, sosial dan lainnya) sebesar 31,2 persen, dan terkecil adalah pengeluaran untuk investasi (pendidikan dan kesehatan) hanya sebesar 18,2 persen. Hal ini mengindikasikan bahwa pola konsumsi keluarga terhadap konsumsi pangan masih tergolong besar namun jauh lebih rendah bila dibandingkan dengan hasil penelitian Suhardjo, dan Hardinsyah, Retnaningsih, (Mangkuprawira, 2002) yaitu berkisar antara 6o-7o persen.

\section{Kesejahteraan Ekonomi Subjektif}

Berdasarkan hasil wawancara dengan keluarga contoh diperoleh informasi bahwa distribusi tingkat kesejahteraan ekonomi subjektif (subjective economic well-being) di daerah penelitian relatif cukup baik. Hal ini ditandai dengan persentase keluarga di wilayah penelitian yang merasa puas dalam pemenuhan keperluan mereka sehari-hari, baik kebutuhan pangan, nonpangan maupun pemenuhan kebutuhan investasi relatif memuaskan yaitu mencapai 6,27 persen. Apabila dikelompokkan, ternyata tingkat kepuasan tertinggi terdapat pada pemenuhan kebutuhan pangan yaitu mencapai 74,2 persen, pemenuhan terhadap kebutuhan nonpangan sebesar 63,7 persen, sedangkan kepuasan terhadap pemenuhan kebutuhan investasi hanya 45,9 persen.

\section{Keterkaitan Modal Sosial dengan Kesejahteraan Ekonomi Keluarga}

Tabel 1. Sebaran Contoh Menurut Tingkat Pengeluaran Keluarga, 2013

\begin{tabular}{|c|c|c|c|}
\hline \multirow{2}{*}{ No } & \multirow{2}{*}{$\begin{array}{l}\text { Tingkat Pengeluaran Keluarga (Rp.ooo/ } \\
\text { kapita/tahun) }\end{array}$} & \multicolumn{2}{|c|}{ Jumlah Responden } \\
\hline & & Absolut & Relatif \\
\hline o1 & Sangat miskin $(<R p .2 .040)$ & 10 & 7.6 \\
\hline 02 & Miskin (Rp.2.040 - Rp.2.720) & 18 & 13.6 \\
\hline 03 & Hampir berkecukupan (Rp.2.720-Rp.4.08o) & 60 & $45 \cdot 5$ \\
\hline 04 & Berkecukupan ( > Rp.4.08o) & 44 & $33 \cdot 3$ \\
\hline- & Total & 132 & 100,0 \\
\hline- & Rata-rata $(R p)$. & \multicolumn{2}{|c|}{3.862 .000} \\
\hline
\end{tabular}




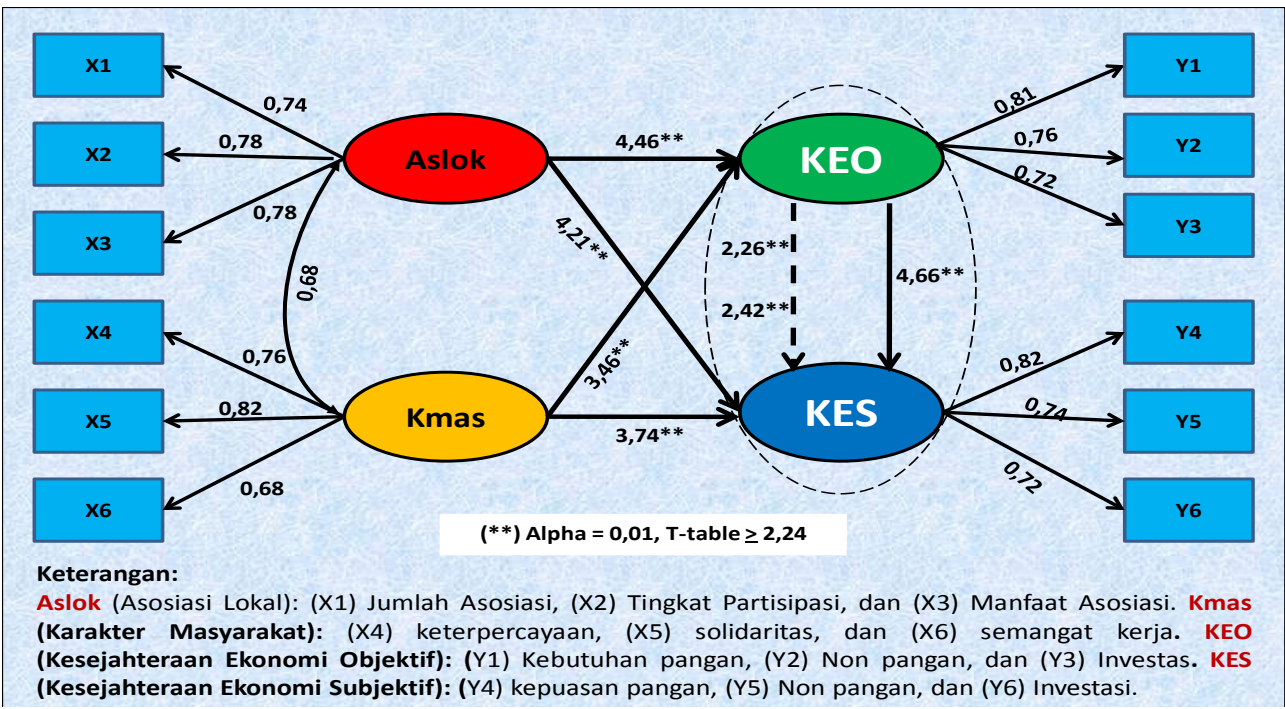

Gambar 1. Hubungan Struktural antara Faktor Modal Sosial dengan Kesejahteraan Ekonomi Keluarga

Keterkaitan modal sosial terhadap kesejahteraan ekonomi keluarga (economic well-being) dianalisis dengan menggunakan model SEM. Melalui model ini dapat diketahui pengaruh atau hubungan antarkontrak secara kausalitas. Sesuai dengan hipotesis, sehingga variabel konstrak terdiri dari empat bagian variabel laten, yakni: (1) Asosiasi Lokal (Aslok) dengan loading variabel: ( $\left.\mathrm{X}_{1}\right)$ jumlah asosiasi yang diikuti, $\left(\mathrm{X}_{2}\right)$ tingkat partisipasi, dan $\left(\mathrm{X}_{3}\right)$ manfaat asosiasi, (2) Karakter Masyarakat (Kmas) dengan loading variabel: ( $\left.\mathrm{X}_{4}\right)$ kepercayaan, ( $\left.\mathrm{X}_{5}\right)$ solidaritas, dan (X6) semangat kerja, (3) Kesejahteraan Ekonomi Objektif (KEO) dengan loading variabel: (Y1) kebutuhan pangan, ( $\left.\mathrm{Y}_{2}\right)$ non-pangan, dan $\left(\mathrm{Y}_{3}\right)$ kebutuhan investasi sumberdaya manusia, (4) Kesejahteraan Ekonomi Subjektif (KES) dengan loading variabel: ( $\left.\mathrm{Y}_{4}\right)$ pemenuhan kebutuhan pangan, ( $\left.\mathrm{Y}_{5}\right)$ non-pangan, dan (Y6) pemenuhan kebutuhan investasi sumberdaya manusia. Hasil pengujian menunjukkan bahwa pengaruh modal sosial terhadap tingkat kesejahteraan ekonomi keluarga di wilayah penelitian cukup valid, karena nilai-nilai alat uji yang digunakan melebihi dari cut-off value. Seperti nilai GFI (Goodness of Fit Index) melebihi dari nilai standar yaitu 0,92 atau lebih besar dari o,9o, nilai CFI (Comparative Fit Index) juga melebihi nilai standar yaitu o,95 atau lebih besar dari 0,94, hal yang sama juga ditunjukkan oleh nilai RMSEA (Root Mean Square Error of Approximation) lebih kecil dari nilai standar yaitu yaitu 0,07 atau lebih kecil dari o,o8 (Joreskog E Sorbon: Freund, dan Carneli, 2004: 104). Keterkaitan modal sosial dengan kesejahteraan ekonomi keluarga di daerah penelitian dapat dilihat pada Gambar 1. Seperti terlihat pada Gambar 1, variabel laten asosiasi lokal (Aslok) misalnya yang terdiri dari tiga dimensi yakni: jumlah asosiasi, tingkat partisipasi, dan manfaat asosiasi memiliki nilai loading yang cukup signifikan. Melalui model diketahui item loadings $\left(\mathrm{X}_{1}\right)$ jumlah asosiasi yang diikuti $(\lambda=$ $0,74),\left(X_{2}\right)$ tingkat partisipasi $(\lambda=0,78)$, dan $\left(\mathrm{X}_{3}\right)$ manfaat asosiasi $(\lambda=0,78)$. Hal yang sama juga ditunjukkan oleh item loadings pada variabel laten karakter masyarakat dan kesejahteraan ekonomi keluarga semuanya menunjukkan nilai $(\lambda)$ yang signifikan.

Hasil analisis menunjukkan bahwa variabel modal sosial (asosiasi lokal dan karakter masyarakat) baik secara langsung maupun tidak langsung berpengaruh positif sangat nyata dan signifikan terhadap tingkat kesejahteraan ekonomi objektif dan kesejahteraan ekonomi subjektif keluarga (subjective economic well-being) dengan nilai betha $(\beta)$ masing-masing adalah 4,46 dan 3,74. Artinya, semakin tinggi tingkat modal sosial yang dimiliki oleh keluarga 
maka semakin baik pula tingkat kesejahteraan mereka.

Modal sosial lain yang cukup penting dalam meningkatkan kesejahteraan ekonomi keluarga adalah kelompok "handel". Melalui kelompok ini, penghasilan keluarga dapat bertambah karena adanya hasil dari nilai kerja anggota keluarga dalam kelompok kerja bersama (collective action). Rata-rata anggota keluarga terlibat dalam kegiatan kelompok handel yaitu dua orang dengan frekuensi kerja selama sebulan dua kali dan setahun sepuluh bulan kerja efektif dengan nilai per setiap kegiatan kelompok handel per orang rata-rata sebesar Rp. 45.0oo,- dan melalui hasil analisis diperoleh bahwa kegiatan kelompok handel dapat memberikan kontribusi terhadap penghasilan keluarga sebesar Rp.990.00o,- per tahun (5,05\%) dari total penghasilan keluarga. Hasil temuan ini didukung oleh hasil penelitian yang dilakukan oleh Grootaer (Suandi, 2011) bahwa setiap satu orang anggota keluarga aktif mengikuti kegiatan asosiasi lokal terutama asosiasi bidang produksi dapat meningkatkan penghasilan keluarga sebesar 6,2 persen per kapita per tahun.

Studi yang sama juga ditemui di Amerika Latin, bahwa terdapat perbedaan positif sangat nyata dan signifikan dalam tingkat keaktifan anggota keluarga pada kegiatan asosiasi lokal dalam meningkatkan kesejahteraan ekonomi keluarga (Durkin, 2000: 2). Disisi lain, modal sosial dapat berperan dalam mendapatkan berbagai akses fasilitas publik di masyarakat, seperti: pengadaan air dan irigasi, kredit, dan input pertanian/ teknologi. Besarnya akses modal sosial ini karena adanya jaringan yang dibangun pada berbagai kelompok (produksi dan sosial) di masyarakat. Hasil penelitian ini tidak jauh berbeda dengan hasil temuan Haddad (2002: 2) di Afrika Selatan bahwa keberadaan modal sosial (jaringan sosial) individu rumahtangga yang kuat ternyata dapat berperan untuk mendapatkan berbagai bentuk akses dalam masyarakat.

2"handel" artinya sistem kerja kelompok (kalbu) dengan mengambil upahan dan setiap mendapat upahan, penghasilannya disimpan terlebih dahulu dan dibagikan dalam satu tahun sekali.

\section{SIMPULAN}

Modal sosial (asosiasi lokal dan karakter masyarakat) yang terdapat di daerah penelitian dan dimiliki responden tergolong tinggi. Asosiasi lokal yang dimiliki dan diikuti responden di daerah penelitian cukup bervariatif baik dilihat dari jumlah asosiasi yang diikuti, tingkat partisipasi maupun manfaat dari asosiasi lokal itu sendiri dengan distribusi rata-rata mencapai 76 persen, dan tingkat keterpercayaan, solidaritas, dan semangat kerja yang dimiliki juga tinggi yaitu mencapai 68 persen. Hal ini mengindikasikan bahwa kepemilikan modal sosial bagi responden di daerah penelitian cukup tinggi dan kuat.

Tingkat kesejahteraan petani proxy pengeluaran petani per tahun sebesar Rp. 19.310,000.- dan jumlah pengeluaran ini di atas rata-rata tolok ukur kesejahteraan dengan pendekatan Badan Pusat Statistik (2010) (Rp. 13.710.000,00). Persentase terbesar dialokasikan untuk pangan kebutuhan pangan (50,6\%), non-pangan (sandang, energi, komunikasi, sosial dan lainnya) sebesar 31,2 persen, dan terkecil adalah pengeluaran untuk investasi (pendidikan dan kesehatan) hanya sebesar 18,2 persen. Mengacu kepada alokasi pengeluaran, tingkat ekonomi petani di daerah penelitian tergolong relatif kaya dengan distribusi keluarga yang tergolong pada kelompok sejahtera mencapai 78,8 persen, sedangkan kelompok miskin hanya 21,2 persen.

Modal sosial (asosiasi lokal dan karakter masyarakat) baik secara langsung maupun tidak langsung berpengaruh positif sangat nyata terhadap kesejahteraan ekonomi objektif dan kesejahteraan ekonomi subjektif petani. Artinya, semakin tinggi tingkat modal sosial yang dimiliki oleh petani maka semakin baik pula tingkat kesejahteraan petani sehingga pada gilirannya dapat meningkatkan ekonomi masyarakat. Peran modal sosial terhadap pembangunan ekonomi petani di daerah penelitian yaitu melalui kegiatan "handel".

Kebijakan pembangunan untuk meningkatkan kesejahteraan petani di daerah perdesaan perlu mempertimbangkan in- 
dikator "modal sosial" sebagai variabel penentu pembangunan tersebut. Modal sosial memiliki nilai kearifan lokal terjalin secara turun temurun yang menjadi kebiasaan dan kekuatan dalam kehidupan masyarakat sehari-hari.

Penguatan modal sosial sangat tepat dalam pemberdayaan masyarakat perdesaan untuk mempercepat pembangunan ekonomi daerah dan kesejahteraan petani karena modal sosial memeliki kekuatan dalam menjalinkan hubungan antarkelompok masyarakat dan relasi.

\section{DAFTAR PUSTAKA}

Anonim. 2012. Tingkat Upah Minimum Penduduk Provinsi Jambi tahun 2012. Jambi: Badan Pusat Statistik (BPS) Jambi.

Dasgupta F, dan I, Serageldin. 200o. Social Capital: A Multifaceted Perspective. The World Bank. Washington: D.C. ISBN o-8213-4562-1.

Flores, M. dan Fernando. 2003. Social Capital and Poverty Lessons from Case Studies in Mexico and Central America. ESA Working Paper No. 03-12. Vol 25, Number 1. Agricultural and Development Economics Division, The Food and Agricultural Organization of the United $\mathrm{Na}$ tions.

Freund, A., dan Abraham, C. 2004. "The Relationship between Work Commitment and Organizational Citizenship Behavior among Lawyers in The Private Sector." The Journal of Behavioral and Applied Management. 5 (2): 93-113

Haddad, L., dan John M. 20oo. Social Capital and Household Well-being in South Africa: Patways of Influnce. Prepered for presentation at the Study of African Economies. Washington: International Food policy Research Institute. DC 20006 USA.

Hastuti, D. 2006. "Analisis Pengaruh Model Pendidikan Prasekolah pada Pembentukan Anak Sehat, Cerdas dan Berkarakter Secara Berkelanjutan." Disertasi. Bogor: Sekolah Pascasarjana Institut Pertanian Bogor.

Mangkuprawira, S. 2002. "Analisis Pendapatan dan Pengeluaran Keluarga di Daerah Industri Tenun Pedesaan." Media Gizi E Keluarga. 25(2)

Milligan, S., Fabian, A., Coope, P., dan Errington C. 2006. Family Wellbeing Indicators from the 1981-2001 New Zealand Cencuses. New Zealand: Published in June 2006 by Statistics New Zealand in Conjunction with The University of Auckland and University of Otago. 2006, ISBN o-478-26982-X.

Strauss, J., Kathleen B., Agus D., Yulia H., Daan P., Elan S., Bondan S., Sukamdi, dan Firman W. 2004. Indonesian Living Standards: Before and After the Financial Crisis. RAND Corporation, Santa Monica, USA, and Institute of Southeast-Asian Studies, Singapure.

Suandi, 2011. Studi Modal Sosial dan Ketahanan Pangan Keluarga di Daerah Perdesaan Provinsi Jambi. Proseding Seminar Nasional: Hasil Penelitian Dosen Pertanian. Volume III, Februari 2011. Jambi: Fakultas Pertanian Universitas Jambi. ISBN: 978-602-97051-4-0. 